\title{
Досвід лікування розшаровуючих аневризм висхідної аорти
}

\author{
Бойко В. В., Бучнєва О. В., Шафер Я. В., Пісклова Ю. В., Богун Ю. В., Крилова О. С.
}

ДУ «Інститут загальної та невідкладної хірургії імені В. Т. Зайцева НАМН» (Харків)

\begin{abstract}
Розшарування аорти першого типу - складна проблема сучасної кардіохірургії. 3 моменту першого досвіду хірургічного лікування розшарування аорти в 1955 році (DeBakey) минуло більше шістдесяти років. У статті описані особливості лікування пацієнтів із гострим розшаруванням висхідної аорти без глибокої гіпотермії з 2012 по 2018 рік у ДУ «ІЗНХ імені В. Т. Зайцева НАМН».
\end{abstract}

Ключові слова: розшаровуюча аневризма висхідної аорти, супракоронарне протезування аорти, антеградна перфузія головного мозку.

Завдяки вдосконаленню можливостей діагностики, моніторингу, технічному забезпеченню оперативних втручань зазнала суттєвих змін хірургічна тактика лікування пацієнтів із розшаруванням аорти $[6,8,9]$. Однак на сьогоднішній день, за даними вітчизняної та зарубіжної літератури, відсутня загальновизнана оптимальна хірургічна тактика ведення хворих із даною патологією. Зараз застосовується декілька варіантів хірургічних операцій при лікуванні розшарування аорти типу А, проте чіткі критерії проведення різних видів операцій не прописані ні у вітчизняній, ні в закордонній літературі [1, 7, $10,12]$.

Суперечливою є тактика захисту внутрішніх органів інтраопераційно. До цього часу точиться дискусія про необхідність перетискання аорти або використання відкритої техніки [3, 5, 11]. Немає єдиної думки і стосовно використання певного температурного режиму. Питання застосування глибокої гіпотермії також продовжує обговорюватися, хоча багатьма хірургами визнана необхідність цієї тактики [2, 4].

Мета роботи - представити результати позитивного досвіту хірургічного лікування розшаровуючих аневризм аорти типу А без використання глибокої гіпотермї.

Матеріали та методи. Протягом 2012-2018 рр. у ДУ «IЗНХ імені В. Т. Зайцева НАМН» прооперовано 45 хворих із діагнозом розшаровуюча аневризма аорти типу А. Чоловіків було 36 (80\%), жінок - 9 (20\%). Вік хворих коливався в межах 32-76 років (у середньому 54 роки). Одна пацієнтка була оперована в підгострій стадії розшарування, а 44 пацієнти - у гострій (час від моменту розшарування до двох тижнів), з них 29 пацієнтів оперовані в період до третьої доби від розшарування.

Діагностика розшаровуючої аневризми висхідної аорти базувалася на даних комп'ютерної томографії. Лише у трьох випадках, у зв'язку з важким станом, діагностування проводилося за допомогою черезстраво- хідної та трансторакальної ехокардіоскопії. Враховувались клінічні дані захворювання, дані рентгенологічного обстеження. Коронарографія та аортографія була виконана у 2 (4,4\%) пацієнтів, яких було доставлено 3 підозрою на інфаркт міокарда.

Переважна кількість хворих мали I тип розшарування відповідно до класифікації De Bakey - 30 (66,7\%), a $15(33,3 \%)$ пацієнтів - II тип. Ознаки мальперфузії були у $31(68,9 \%)$ хворого. В перші 24 години після госпіталізації прооперовано 42 (93,3\%) хворих.

Супракоронарне протезування аорти та частково дуги з ресуспензією аортального клапана виконано у $21(46,7 \%)$ хворого, у 1 (2,2\%) пацієнта висхідна аорта протезувалася цілком із дугою з подальшою реімплантацією брахіоцефальних судин, а у 2 (4,4\%) пацієнтів знадобилося реімплантація брахіоцефального стовбура, в одному випадку за допомогою протеза. У 3 (6,6\%) хворих виконувалося супракоронарне протезування аорти з протезуванням аортального клапана. У 18 (40\%) хворих із розшаровуючою аневризмою аорти проводилося протезування аорти в модифікації Yacoub (1979).

Операції виконувались крізь серединну стернотомію, в умовах штучного кровообігу, в умовах помірної $\left(28{ }^{\circ} \mathrm{C}\right)$ або глибокої $\left(18-20{ }^{\circ} \mathrm{C}\right)$ гіпотермії з унілатеральною селективною антеградною перфузією головного мозку, крім одного випадку без перфузії головного мозку.

Клапанзберігаючі операції виконано у 42 (93,3\%) пацієнтів, у 3 (6,7\%) виконано протезування аортального клапана у зв'язку із супутнім стенозом аортального клапана. Додаткове аортокоронарне шунтування в праву коронарну артерію виконано у 3 (6,7\%) хворих у зв'язку з відривом останньої та неможливістю реімплантації.

Результати та обговорення. До 2012 року в ДУ «IЗНХ імені В. Т. Зайцева НАМН» операції з приводу розшаровуючих аневризм висхідного відділу аорти не вико- 
нувалися. 3 огляду на те, що і натепер ас немає єдиної доктрини лікування хворих із цім діагнозом, кожна операція відшліфовувала специфічний підхід до цієї групи пацієнтів.

Під час двох перших операцій, враховуючи наявність практики судинної хірургії, ми забезпечували артеріальну перфузію крізь ліву пахвову артерію: в одному випадку - за допомогою прямої канюляції, в іншому - крізь синтетичний протез, попередньо ушитий кінець у бік. Обидва рази перфузії внутрішніх органів не було достатньо, тому довелося провести реканюляцію в аорту після стернотоміі. На сьогодні для артеріальної перфузії та унілатеральної селективної антеградної перфузії головного мозку ми використовуємо тільки ліву підключичну артерію, яка встановлюється до стернотомії.

Використання канюляції тільки стегнової артерії для забезпечення артеріальної перфузії не забезпечило антеградної перфузії головного мозку в пацієнта з відривом інтими аорти на рівні брахіоцефального стовбура, що призвело до більшого післяопераційного періоду в зв'язку з неврологічними порушеннями.

Відсутність клапанвмісних кондуїтів призвело до використання окремого протезування аортального клапана і супракоронарного протезування аорти, а також поширення пластики аортального клапана, навіть при великій анулаортальній ектазії. Рутинне використання прокладок із тефлону для формування всіх анастомозів, наявність можливості використання апарату «Cell Saver» зумовило зменшення коагуляційних кровотеч із несприятливим результатом.

Висновки. Накопичення досвіду організації ургентних операцій, хірургічного досвіду, урахування особливостей функціонування багатопрофільної клініки та функціонування додаткових служб дозволило знизити післяопераційну летальність у пацієнтів із гострою розшаровуючою аневризмою аорти типу А з 50\% (на перші 10 прооперованих хворих) до 1\% (останні 10 прооперованих хворих). Загалом летальність склала 26,66\% (12 пацієнтів).

\section{Література}

1. Непосредственные и отдаленные результаты хирургического лечения аневризм и расслоений восходящего отдела и дуги аорты / Ю. В. Белов, А. Б. Степаненко, Ф. В. Кузнечевский // Российский кардиологический журнал. - 2004. - № 5: - С. 5-16.

2. Технологии хирургического лечения аневризм грудного и торакоабдоминального отделов аорты / Ю. В. Белов, А. Б. Степаненко, А. П. Гене и др. // Анналы Рос- сийского научного центра хирургии РАМН. - 2001.Вып. 10. - С. 22-29.

3. Хирургическое лечение аневризм и расслоений восходящего отдела и дуги аорты / Ф. В. Кузнечевский // Российский кардиологический журнал. - 2002. № 6. - С. 92-101.

4. Хирургическое лечение гигантских аневризм восходящего отдела и дуги аорты в условиях глубокой гипотермии и остановки кровообращения с периферическим подключением аппарата искусственного кровообращения / Ю. В. Белов. А. П. Гене, А. Б. Степаненко и др. // Хирургия. - 2003. - № 5. - С. 4-8.

5. Acute Aortic Dissection: Guide Through the Aggressive Disease / Paperback - June 30, 2013 / Dr. Michal Schafer, Dr. Cynthia L. Norrgran (Contributor).

6. Acute Aortic Dissection: pathogenesis, risk factors and diagnosis / Gawinecka Joannaa, Schönrath Felixb, von Eckardstein Arnolda // Swiss Med Wkly. - 2017. Vol. 147. - P. 1-7. doi:10.4414/smw.2017.14489.

7. Aortic dissection:Patients true stories and the innovations that saved their lives / Curatore / Germano Melissano, Roberto Chiesa / Milano, Italy / ISBN-9788870515657 / Published in December 2016.

8. Chronobiology of Acute Aortic Dissection in the Marfan Syndrome (from the National Registry of Genetically Triggered Thoracic Aortic Aneurysms and Cardiovascular Conditions and the International Registry of Acute Aortic Dissection) / Siddiqi H. K., Luminais S. N., Montgomery D. (et al.) //- 2017 Mar. - Vol. 119 (5). P. 785-789. /doi: 10.1016/j.amjcard.2016.11.021/

9. Clinical features and prognosis of patients with acute aortic dissection in China / Lujing Zhao, Yanfen Chai, Zhigang Li // Emergency Department of Tianjin 4th Center Hospital, China. - Vol. 45, issue 2. - P. 823-829 / https:// doi.org/10.1177/0300060517699319. Issue published: April 1, 2017.

10. A Contemporary Review of Acute Aortic Dissection/ Subhi J. Al'Aref, Leonard N. Girardi, Richard Devereux (et al.) // Department of Cardiothoracic Surgery. NewYork Presbyterian Hospital - Weill Cornell Medical Center/ New York, NY 10065, Published date: July 14, 2015.

11. Mortality in patients with acute aortic dissection type A: analysis of pre- and intraoperative risk factors from the German Registry for Acute Aortic Dissection Type A (GERAADA) / Lars Oliver Conzelmanna, Ernst Weigangb, Uwe Mehlhorna et al. // European Journal of Cardio-Thoracic Surgery. - 2016. - Vol. 49. - p.44-52. doi:10.1093/ejcts/ezv356/

12. Surgical repair and reconstruction of aortic arch in Debakey type I aortic dissection: recent advances and singlecenter experience in the application of branched stent graft / Qian Zhang, Xiaochun Ma, Wenlong Zhang et al. // J Cardiothorac Surg. - 2017. - Vol. 12. - P. 86 / Published online 2017 Oct. / doi: 10.1186/s13019-017-0649-6. 


\title{
Experience of acute ascending aortic dissection treatment
}

\author{
Boiko V. V., Buchnieva O. V., Shafer Y. V., Pisklova Y. V., Bogun Y.V., Krylova O. S. \\ ST “Zaycev V. T. Institute of General and Urgent Surgery AMS of Ukraine"
}

Acute aortic dissection, type A, is a demanding issue in cardiac surgery. Since the first attempts of surgical treatment among patients with acute aortic dissection in 1955(DeBakey) more than sixty years has passed. The article describes the features of surgical treatment among patients with acute aortic dissection without circulatory arrest between years 2012 and 2018 in ST "Zaycev V. T. Institute of General and Urgent Surgery AMS of Ukraine”.

Key words: acute ascending aortic dissection, supracoronary ascending aorta replacement, antegrade cerebral perfusion.

\section{Опыт лечения расслаивающих аневризм восходящей аорты}

\author{
Бойко В. В., Бучнева О. В., Шафер Я. В., Писклова Ю. В., Богун Ю.В., Крылова А. С. \\ ГУ «Институт общей и неотложной хирургии имени В.Т. Зайцева НАМН» (Харьков)
}

Расслоение аорты - сложная проблема современной кардиохирургии. С момента первого опыта хирургического лечения расслоения аорты в 1955 году (DeBakey) прошло более шестидесяти лет. В статье описаны особенности лечения пациентов с острым расслоением восходящей аорты без циркуляторного ареста с 2012 по 2018 год в ГУ «ИОНХ имени В. Т. Зайцева НАМН».

Ключевые слова: расслаивающая аневризма восходящей аорты, супракоронарное протезирование аорты, антеградная перфузия головного мозга. 